\title{
FUNDACJA „DZIEŁO NOWEGO TYSIĄCLECIA” JAKO ODPOWIEDŹ NA WYZWANIA WOBEC WYCHOWAWCZEJ I CHARYTATYWNEJ POSŁUGI KOŚCIOŁA
}

\author{
THE FOUNDATION “OPUS OF THE NEW MILLENNIUM" \\ AS AN ANSWER TO CHALLENGES OF PEDAGOGIC \\ AND CHARITABLE SERVICE OF THE CHURCH
}

\begin{abstract}
A bstract. The Second Vatican Council drew attention to the mission of seculars in the church and in the world. The effect of decisions made on the Council was enhancement of the importance of laity, especially young people. At the end of $20^{\text {th }}$ century the church detected the need of taking care of young generation, which appropriately shaped would make a contribution to change the social structures to build up a civilization of love. As a result, the Foundation "Opus of the New Millennium" was established. One of the main goals of this organization is to help gifted youth coming from poor families and living in small villages. The scholarship program include financial support as well as Christian formation of scholars in the vein of teachings of John Paul II. Charges of foundation, being grateful for received help, take different actions which are the fruit of formation and also confirmation of building the "living memorial of the Pope". It means that they live according to values preached by the Holy Father and spread them around the world.
\end{abstract}

Key words: youth; the Foundation "Opus of the New Millennium"; scholarship program; Christian formation; John Paul II.

Mgr Paulina SkóRnickA - doktorantka w Instytucie Nauk Teologicznych Katolickiego Uniwersytetu Lubelskiego Jana Pawła II; adres do korespondencji: ul. Grota Roweckiego 66, 26-600 Radom; e-mail: paulina.skornicka@wp.pl; ORCID: http://orcid.org/0000-0003-2305-3431

Paulina SKóRnicka - Ph.D. student at Institute of Theological Sciences of the John Paul II Catholic University of Lublin; address for correspondence: ul. Grota Roweckiego 66, 26-600 Radom; e-mail: paulina.skornicka@wp.pl; ORCID: http://orcid.org/0000-0003-2305-3431 
Kościół, szczególnie po Soborze Watykańskim II, zwrócił uwagę na rolę, jaką w kształtowaniu chrześcijańskiej przyszłości odgrywają ludzie świeccy, zwłaszcza młodzi. Młode pokolenie jawi się jako potężna siła, wywierająca wpływ zarówno na porządek społeczny, jak i przekazywanie światu chrześcijańskiego orędzia. Z tej perspektywy wynika potrzeba towarzyszenia młodzieży, dostrzegania jej problemów, różnych sytuacji życiowych, w których się znajduje, aby prowadzić ją do Chrystusa, by z Nim i na Nim budowała własne życie, a dzięki temu mogła odkryć swoje wyjątkowe miejsce w Kościele i świecie ${ }^{1}$. Na przełomie drugiego i trzeciego tysiąclecia, gdy cała wspólnota Kościoła przygotowywała się do obchodów Wielkiego Jubileuszu, powstawało wiele różnych inicjatyw skierowanych do ludzi młodych, mających na celu ich formację w duchu chrześcijańskim, aby stawali się uczniami i świadkami Chrystusa we współczesnym społeczeństwie i z odwagą przekazywali ewangeliczne orędzie w swoich rodzinach, miastach, środowiskach życia. Taką inicjatywą, podjętą przez Kościół w Polsce, było powołanie Fundacji „Dzieło Nowego Tysiąclecia”. Jednym z założeń tej organizacji stało się niesienie pomocy materialnej utalentowanym młodym ludziom, pochodzącym z niezamożnych rodzin, połączone $\mathrm{z}$ odpowiednią formacją w duchu nauczania Jana Pawła II. Fundacja ta wpisała się na stałe w obraz działalności Kościoła w Polsce, wciąż jednak istnieje niewiele naukowych opracowań jej genezy i funkcjonowania. $Z$ tego względu przygotowana została publikacja, której głównym problemem jest udzielenie odpowiedzi na pytanie o motywy powstania Fundacji oraz o treści i sposoby jej działalności wpisujące się w charytatywną i edukacyjną misję Kościoła.

\section{PRZEMIANY KULTUROWE WEZWANIEM DO DZIAŁALNOŚCI WYCHOWAWCZEJ}

Współczesny człowiek żyje w świecie bardzo szybko postępujących przemian, dotykających wszystkich wymiarów jego egzystencji. Wszechogarniający postęp naukowy oraz techniczny staje się najważniejszym wyznacznikiem rozwoju. Nowa kultura i cywilizacja przejawia zainteresowanie osobą ludzką, jednak wyłącznie na płaszczyźnie fizycznej, doczesnej, jednocześnie pozostając obojętną wobec sfery wewnętrznej, duchowej. Prowadzi to do poważnego wypaczenia na gruncie antropologicznym. Zmianie ulega stosunek człowieka wobec świata, społeczeństwa, a ostatecznie również wobec Boga².

\footnotetext{
${ }^{1}$ Por. Jan Pawel II, Adhortacja apostolska „Ecclesia in America” (Meksyk, 1999), nr 47.

${ }^{2}$ Por. Mieczysław Majewski, Aktualne wyzwania katechetyczne (Kraków: Wyd. Poligrafia Salezjańska, 1997), 9-12.
} 
Powszechnym zjawiskiem staje się pogoń za modą oraz bogactwem. Charakterystyczną cechą społeczeństwa jest nieograniczona chęć posiadania, podążania za nowinkami. Wartość ma to, co przynosi wymierną korzyść materialną. W takiej perspektywie człowiek staje się narzędziem do osiągnięcia zamierzonych celów, przyjemności, zatracając świadomość swojej niezbywalnej godności dziecka Bożego i współpracownika w dziele stworzenia ${ }^{3}$. Osoba ludzka coraz częściej rości sobie prawo do ingerowania w świat natury, przekształcania go i kierowania nim według własnego zamysłu, bez odniesienia do Boga Stwórcy. Społeczeństwo odznacza się otwartością na problemy o zasięgu państwowym, kontynentalnym czy światowym, jest gotowe do niesienia pomocy na szeroką skalę. Przy tym wszystkim niejednokrotnie zapominając o osobach żyjących w najbliższym otoczeniu, borykających się z równie wielkimi problemami. W aglomeracjach miejskich życie staje się anonimowe, a ludzie niechętnie tworzą wspólnoty. Wolą zabiegać o swój indywidualny cel, pozostając w odosobnieniu. Sytuacja taka staje się jednak często powodem frustracji, przygnębienia, rezygnacji, przy jednoczesnej niechęci do jakichkolwiek zmian. Taka kultura ma potężnego sprzymierzeńca i propagatora w środkach masowego przekazu 4 .

Demokratyczne i pluralistyczne społeczeństwo gwarantuje wolność poszukiwań i dokonywania wyborów. W takim świecie chrześcijaństwo jawi się ludziom jako jedna z opcji, i to niekoniecznie najbardziej atrakcyjna. Współczesna kultura, jak stwierdzają autorzy Ogólnej instrukcji katechetycznej, ,nierzadko odwraca zainteresowanie ludzi od spraw religijnych i utrudnia wewnętrzną troskę o sprawy religijne. Dla wielu Bóg wydaje się trudniej dostrzegalny, mniej konieczny, mniej potrzebny do wytłumaczenia spraw z zakresu życia zarówno osobistego, jak i społecznego"5. Bez wątpienia, obecnie coraz częściej mamy do czynienia ze społeczeństwem zsekularyzowanym, a nawet zateizowanym.

Przez wieki społeczeństwo było w większości chrześcijańskie, odwoływało się do obiektywnych norm moralnych, przykazań Dekalogu, a wiara była integralną częścią życia zarówno osoby ludzkiej, jak i całego społeczeństwa. Jednakże dotychczas przyjmowana hierarchia wartości współcześnie coraz częściej jest kwestionowana. Religia, z jej zewnętrznymi przejawami, jest postrzegana jako wyraz zacofania, jako bariera na drodze postępu ${ }^{6}$. Można zauważyć spadek zainteresowania

\footnotetext{
${ }^{3}$ Por. Małgorzata KróLczYK, „Autorytet moralny - wyzwanie dla wychowawców współczesnej młodzieży", Studia Leopoliensia 12(2019), 111-2.

${ }^{4}$ Por. Majewski, Aktualne wyzwania katechetyczne, 9-18.

${ }^{5}$ Kongregacja DS. Kleru, Directorium catechisticum generale. Ogólna instrukcja katechetyczna (Rzym, 1971), nr 5.

${ }^{6}$ Por. Jan Palyga, „Na drodze wiary i niewiary”, Communio 8, nr 3 (1988), 22.
} 
religijnym aspektem życia. Wiara traktowana jest jako indywidualna sprawa jednostki, która coraz rzadziej odczuwa potrzebę wyrażania jej poprzez podejmowane praktyki religijne. Wielu, zwłaszcza młodych ludzi, ostateczny sens i cel życia upatruje na płaszczyźnie doczesnej, w osiąganiu sukcesów zawodowych i materialnych. W centrum uwagi staje człowiek, który jest samowystarczalny, sam może zaspokoić swoje potrzeby. Nierzadko deklaruje się jako osoba wierząca, jednak jego doświadczenie wiary jest płytkie, subiektywne, w coraz mniejszym stopniu tożsame z wiarą katolicką ${ }^{7}$. Odrzucenie Boga i Jego przykazań oraz relatywizm moralny nie dają jednak odpowiedzi na pytania o ostateczny cel i sens życia. Przeciwnie, dzisiejszy człowiek coraz bardziej czuje się zagubiony i bezradny, niby zanurzony w świat rzeczy, ale jednocześnie wyobcowany ${ }^{8}$.

Na wpływ opisanych przejawów współczesnej kultury narażeni są zwłaszcza ludzie młodzi. Jak czytamy w Pastores dabo vobis:

młodzi ulegają fascynacji tak zwanym «społeczeństwem konsumpcyjnym», które zniewala ich i zamyka w kręgu indywidualistycznej, materialistycznej i hedonistycznej interpretacji ludzkiej egzystencji. Jedynym ideałem życiowym staje się wówczas dobrobyt materialny, który trzeba osiągnąć za wszelką cenę i bezwarunkowo. Odrzuca się zatem wszystko to, co wiąże się z ofiarą, oraz rezygnuje z trudu poszukiwania wartości duchowo-religijnych i życia zgodnego z nimi .

Okres adolescencji jest nie tylko czasem między dzieciństwem a dorosłością. Na tym etapie człowiek poszukuje własnej drogi życiowej, stawia pytania o wartości, którymi powinien się kierować, aby mieć na uwadze ostateczny cel i sens egzystencji. Jest to czas nie tylko przejściowy, związany z konkretną liczbą lat, ale przede wszystkim zadany przez Boga. Młode pokolenie w tym wieku dokonuje fundamentalnych wyborów, które mają znaczenie nie tylko indywidualne i zakorzenione w teraźniejszości, ale wywierają wpływ na całą społeczność ludzką zarówno teraz, jak i w przyszłości ${ }^{10}$.

Ojciec Święty Jan Paweł II od początku pontyfikatu w swoich orędziach, przemówieniach, spotkaniach z młodzieżą podkreślał wielką wartość tego okresu egzystencji. Z jednej strony akcentował konieczność odrzucenia wszelkich myśli o bierności, nieudolności, a z drugiej wzywał do podjęcia wysiłku w dążeniu do wielkich i wzniosłych celów. Nawoływał do poszukiwania prawdy i postępowania według jej zasad,

\footnotetext{
${ }^{7}$ Por. P. MĄкоSA, „Znaki czasu dla katechezy w Polsce”, Verbum Vitae 35(2019), nr 35, s. 466-7.

${ }^{8}$ Por. M. DzIEwIECKI, „Wychowanie nastolatków a stawianie wymagań”, Zeszyty Formacji Katechetów 18(2018), nr 3, s. 5.

${ }^{9}$ JAN PAwee II, Posynodalna adhortacja apostolska „Pastores dabo Vobis” o formacji kapłanów we wspótczesnym świecie, Rzym 1992, nr 8.

${ }^{10}$ Por. Jan PaweŁ II, Przekroczyć próg nadziei. Jan Pawet II odpowiada na pytania Vittoria Messoriego (Lublin: RW KUL, 1994), 105-6.
} 
kształtowania w sobie postawy solidarności, zwłaszcza z najbardziej potrzebującymi, budowania cywilizacji miłości, wolności, sprawiedliwości i pokoju ${ }^{11}$. Młodzi ludzie nie tylko są świadkami dokonujących się przemian społecznych, politycznych, kulturowych, ale ze względu na swój młodzieńczy zapał uczestniczą w tych przemianach i stają się ich inicjatorami. Jan Paweł II wielokrotnie przypominał młodzieży, że to od nich zależy przyszłość Kościoła i świata, wyrażając nadzieję, że nie zmarnują tego daru i wykorzystają entuzjazm wiary, radości, nadziei w budowaniu lepszego jutra ${ }^{12}$.

Młodzież, aby mogła sprostać tym oczekiwaniom, potrzebuje odpowiedniej formacji i wychowania. Wybór dobra i tego, co naprawdę wartościowe, jest znacznie trudniejszy niż dążenie do tego, co łatwo osiągalne, pozornie uszczęśliwiające. Dodatkowym utrudnieniem stała się współczesna kultura głównego nurtu, propagująca egoizm, nihilizm, ateizm, laicyzację, lenistwo, manipulację, karierę, bogactwo, przyjemność za wszelką cenę. W takim kontekście wychowanie jawi się jako ochrona teraźniejszego i przyszłego życia, pomoc niesiona młodym ludziom, aby stawali się najlepszą i najpiękniejszą wersją samych siebie i z każdym dniem upodabniali się do Boga ${ }^{13}$. Chodzi także o to, żeby uczyli się troski oraz odpowiedzialności za dobro wspólne, nie rezygnowali z zaangażowania w życie społeczne, ale wnikali w nie i przemieniali od wewnątrz. W czasach współczesnych konieczne jest integralne wychowanie osoby ludzkiej, mające na względzie cel ostateczny, którym jest dom $\mathrm{Ojca}^{14}$. W wychowaniu należy uwzględnić, że współczesny człowiek, zwłaszcza w okresie adolescencji, potrzebuje nie tyle nauczycieli, co świadków, wzorców osobowych. Przykład ich życia, który jest uobecnieniem głoszonych prawd, przemawia dużo mocniej i skuteczniej niż najwznioślejsze formuły i wezwania ${ }^{15}$. Taka formacja jawi się jako trudne, ale konieczne wyzwanie duszpasterskie XXI wieku. Jest ona nieustannie podejmowana przez Fundację „Dzieło Nowego Tysiąclecia”.

${ }^{11}$ Por. JAN PAwEe II, „Spotkanie z młodzieżą «Chrystus jest odpowiedzią na wasze pytania» (Caracas, 28 stycznia 1985)", w Podręcznik pokolenia JP2. Ojcowskie słowo do młodych świata, Polski i Lednicy, red. H. Koźmińska (Poznań: Wyd. Duszpasterstwo Akademickie Dominikanów, 2008), 165.

${ }^{12}$ Por. JAN PAwee II, „Spotkanie z młodzieżą Szwajcarii romańskiej «Macie dać Kościołowi nową młodość» (Fryburg, 13 czerwca 1984)”, w Podręcznik pokolenia JP2, 138; por. JAN PAwEŁ II, „Homilia podczas Mszy świętej dla młodzieży «Podstawowy problem ludzkiego życia» (Lizbona, 14 maja 1982)”, w: Podręcznik pokolenia JPII, 81; Por. JAN PAwe飞 II, „Słowo z okna Pałacu Arcybiskupiego (Kraków, 21 czerwca 1983)", w: Podręcznik pokolenia JPII, 753-4.

${ }^{13}$ Por. DzIEwiecki, „Wychowanie nastolatków”, 5-6.

${ }^{14}$ Por. Arkadiusz OlCzyK, „Horyzonty wychowania moralnego w nauczaniu Karola Wojtyły Jana Pawła II", w Wychowanie w refleksji Karola Wojtyly - Jana Pawła II. Wybrane aspekty, red. Mariusz Sztaba i Anna Różyło (Lublin: Wyd. KUL, 2015), 111.

${ }^{15}$ Por. Pawel VI, Posynodalna adhortacja apostolska ,Evangelii nuntiandi” o ewangelizacji w świecie wspótczesnym (Rzym, 1975), nr 41. 


\section{SYTUACJA EKONOMICZNA WEZWANIEM DO DZIAŁALNOŚCI CHARYTATYWNEJ}

Fundacja „Dzieło Nowego Tysiąclecia” została ustanowiona w 2000 roku przez Konferencję Episkopatu Polski. Powołanie tej organizacji było z jednej strony odpowiedzią Kościoła na ówczesną sytuację społeczną i gospodarczą w Polsce, a z drugiej - owocem papieskiego nauczania, skierowanego do rodaków w czasie siódmej pielgrzymki apostolskiej do Ojczyzny, która odbyła się w 1999 roku ${ }^{16}$.

Długie rządy komunistyczne w Polsce sprawiły, że kraj pod koniec lat 80. XX w. był pogrążony w wielkim kryzysie gospodarczym. Podejmowane próby reform nie przynosiły oczekiwanych rezultatów i kończyły się niepowodzeniem. Wciąż rosnąca inflacja stawała się coraz większym problemem państwowym i społecznym. Była ona spowodowana $\mathrm{z}$ jednej strony wzrostem popytu, niemożliwym do realizacji z powodu zachwiania przemysłu, jak i pogłębiającym się deficytem finansowym ${ }^{17}$. W opinii Polaków żywe było pragnienie zmian panującej rzeczywistości. Znaczący wpływ w tej kwestii odegrał wybór Karola Wojtyły na stolicę piotrową w 1978 roku. Ojciec Święty zawsze był zatroskany o sprawy polskie, wzywał do nadziei w przemianę i poprawę aktualnej sytuacji ${ }^{18}$. Podczas pierwszej wizyty w Ojczyźnie wypowiedział pamiętne słowa na Placu Zwycięstwa w Warszawie: „Wołam, ja, syn polskiej ziemi, a zarazem ja, Jan Paweł II, papież. Wołam z całej głębi tego Tysiąclecia, wołam w przeddzień Święta Zesłania, wołam wraz z wami wszystkimi: Niech zstąpi Duch Twój! Niech zstąpi Duch Twój i odnowi oblicze ziemi. Tej ziemi!"’19. Zmiany zapoczątkowane obradami Okrągłego Stołu w 1989 roku przyniosły wiele pozytywnych przekształceń, jednak nie uniknięto piętrzących się nowych trudności, dotykających zwłaszcza najbiedniejsze warstwy społeczeństwa oraz rodziny wielodzietne. Upadek Państwowych Gospodarstw Rolnych i przemysłu, dotkliwe przekształcenia własnościowe przyczyniły się do wzrostu bezrobocia, zwłaszcza na terenach rolniczych. Utrata pracy, szerząca się bieda stały się codziennością wielu Polaków ${ }^{20}$.

${ }^{16}$ Por. K. Nycz, „Wspólnie budujemy «żywy pomnik» Jana Pawła II”, w: Raport 2000-2010, red. Marek Ziółkowski i in. (Katowice, 2011), 3.

${ }^{17}$ Por. J. Kostecki, Problemy równowagi rynkowej w polityce społeczno-gospodarczej (Warszawa: Wyd. WAP, 1988), 48.

${ }^{18}$ Por. Krzysztof Bielawny, „Sytuacja społeczno-polityczna w Polsce na przełomie tysiąclecia jako kontekst powstania Fundacji „«Dzieło Nowego Tysiąclecia»”, Ateneum Kaptańskie 173, z. 2 (2019), 214-15.

${ }^{19}$ JAN PAwel II, „Homilia w czasie Mszy św. odprawianej na Placu Zwycięstwa (Warszawa, 2 czerwca 1979)", w: Dzieła zebrane, red. P. Ptasznik i in., t. 9 (Kraków: Wyd. M, 2008), 33.

${ }^{20}$ Por. Radosław Patlewicz, Historia polityczna Polski: nowe spojrzenie, t. 2 (Częstochowa: Wyd. 3DOM, 2018), 308-11. 
Pomimo upływu dziesięciu lat od rozpoczętych przemian społeczno-gospodarczych w Polsce, wciąż wiele osób borykało się z trudnościami materialnymi, brakiem środków utrzymania, ubóstwem. Wybrzmiało to w przemówieniach papieskich wygłaszanych podczas pielgrzymki do Polski w 1999 roku, przy okazji odwiedzin między innymi takich miast, jak Zamość, Gliwice czy Sosnowiec. Szczególne znaczenie ma homilia wygłoszona przez Ojca Świętego w Ełku. Jan Paweł II podkreślił w niej, że skutków transformacji w sposób dotkliwy doświadczają ludzie młodzi, którzy niejednokrotnie z powodu biedy zostają pozbawieni możliwości kształcenia i rozwijania swoich talentów. Papież zwracał uwagę rodaków na wciąż obecne przejawy nędzy i wzywał do postawy solidarności z potrzebującymi w duchu miłości i bezinteresowności ${ }^{21}$. Słowa Ojca Świętego znalazły swój wydźwięk w decyzji Episkopatu o przeznaczeniu 700000 złotych, pozostałych po papieskiej pielgrzymce, na powołanie fundacji, która miała $\mathrm{z}$ jednej strony przyczyniać się do upowszechniania w przestrzeni publicznej nauczania Jana Pawła II, a z drugiej być praktyczną realizacją dzieł miłosierdzia ${ }^{22}$.

Działalność Fundacji „Dzieło Nowego Tysiąclecia” realizuje trzy zasadnicze cele, którymi są: „,wpieranie rozwoju kultury i nauki chrześcijańskiej oraz chrześcijańskich mediów w Polsce; podnoszenie szans edukacyjnych młodzieży z małych miast i wsi; upowszechnianie nauczania papieża Jana Pawła II"²3. Szczególnej analizie zostanie poddany drugi nurt działań statutowych, czyli ,podnoszenie szans edukacyjnych młodzieży z małych miast i wsi”. Wypełnianiu tego założenia sprzyja program stypendialny, wprowadzony i realizowany nieprzerwanie od momentu powstania Fundacji. Pierwotnie jego zasięg obejmował 500 stypendystów pochodzących z pięciu wybranych polskich diecezji najbardziej potrzebujących pomocy. Byli to uczniowie uczęszczający do gimnazjum. Pilotażowa próba przyniosła oczekiwane rezultaty i już w kolejnym roku opieką stypendialną objęto 728 gimnazjalistów, a zasięg programu został rozszerzony na kolejne pięć diecezji. W 2002 roku uwzględniono w działaniach stypendialnych Fundacji wszystkie diecezje. Niektórzy uczniowie ukończyli w tym czasie gimnazjum, ale pomimo to otrzymali stypendia na kolejny rok nauki w liceum² ${ }^{24}$. Wypłata stypendiów stała się możliwa dzięki hojności i wsparciu ludzi dobrej woli.

${ }^{21}$ Por. Jan PaweŁ II, „Homilia w czasie Mszy św. (Ełk, 8 czerwca 1999)”, w Jan Paweł II. Pielgrzymki do Ojczyzny. Przemówienia. Homilie (Kraków: Wyd. Znak, 2005), 1060.

${ }^{22}$ Por. Dariusz KowalczyK, „Geneza i rozwój Fundacji Konferencji Episkopatu Polski «Dzieło Nowego Tysiąclecia»”, Ateneum Kapłańskie 173, z. 2 (2019), 235-8.

${ }^{23}$ Statut Fundacji „Dzieło Nowego Tysiąclecia”, Częstochowa 1999, art. 6.

${ }^{24}$ Por. Fundacja „Dzielo Nowego TysiąClecia”, ,Informacja o pracach Fundacji «Dzieło Nowego Tysiąclecia» w okresie kadencji Zarządu 2000-2004”, w Archiwum Fundacji „Dzieło Nowego Tysiąclecia", teczka 1, Sprawozdania, 4-6. 
Obecnie pieniądze pochodzą głównie z prowadzonej corocznie ogólnopolskiej zbiórki z okazji Dnia Papieskiego, przekazywania 1\% podatku dochodowego, jak również od indywidualnych oraz instytucjonalnych darczyńców ${ }^{25}$.

Działalność stypendialna Fundacji stała się permanentna. Objęła uczniów od pierwszej klasy gimnazjum, a po reformie szkolnictwa - po drugim semestrze siódmej klasy szkoły podstawowej, aż do momentu ukończenia studiów wyższych, jeśli uzyskali pozytywną ocenę komisji stypendialnej. Podopieczni Fundacji to osoby pochodzące z niezamożnych rodzin, których dochód na jednego członka nie przekracza 0,7 najniższego wynagrodzenia brutto, mieszkające na terenach wiejskich lub w małych miastach, gdzie liczba mieszkańców nie jest wyższa niż 20000 osób. Ponadto ubiegający się o stypendium muszą odznaczać się wysokimi osiągnięciami w nauce, na przykład średnią ocen nie niższą niż 4,8 w szkole podstawowej, a 4,5 w szkole średniej. Studenci otrzymują stypendium jako kontynuację wcześniejszej opieki stypendialnej ${ }^{26}$. Jak podkreśla kardynał Kazimierz Nycz, przewodniczący Rady Fundacji, „bez pomocy stypendialnej ta zdolna, utalentowana i pochodząca z niewielkich miejscowości młodzież nie byłaby w stanie zdobyć wykształcenia na poziomie odpowiadającym jej nieprzeciętnym możliwościom"²7.

Program stypendialny Fundacji to nie tylko wsparcie materialne udzielane raz w miesiącu utalentowanej młodzieży, stanowiące pomoc i motywację dla jej rozwoju intelektualnego, lecz także stała formacja w duchu wartości bliskich Ojcu Świętemu Janowi Pawłowi II. Wymiar duchowy dla Fundacji jest niezwykle istotny, ponieważ wypływa z troski o integralny rozwój młodego człowieka. Jest realizowany poprzez ukierunkowanie stypendystów na fundament życia, którym jest Chrystus $^{28}$. Dopiero rzeczywiste spotkanie z Chrystusem, takie, jakie stało się udziałem młodzieńca z Ewangelii (por. Mk 10, 17-22), oraz świadoma i dojrzała relacja z Nim, pozwala pełniej żyć, odnaleźć w życiu cel i sens, pozostać w każdej sytuacji człowiekiem sumienia, który cieszy się wiarygodnością i autentycznościąą.

${ }^{25}$ Por. Fundacja „Dzielo Nowego Tysiąclecia”, Raport 2016, red. Anna Bonk i in. (Warszawa, 2017), 9.

${ }^{26}$ Por. Fundacja „Dzielo Nowego Tysiąclecia”, Raport 2017, red. P. Żulewski i in. (Warszawa, 2018, 11.

${ }^{27}$ K. Nycz, „Szanowni państwo!”, w Raport 2000-2015, red. Dariusz Kowalczyk i in. (Warszawa, 2016), 3 .

${ }^{28}$ Por. Krzysztof Mielnicki, „Rekrutacja i formacja stypendystów Fundacji «Dzieło Nowego Tysiąclecia» w diecezji drohiczyńskiej z pastoralnej perspektywy koordynatora”, Ateneum Kapłańskie 173, z. 2 (2019), 341-5.

${ }^{29}$ Por. JAN PAwEe II, „List apostolski do młodych całego świata z okazji Międzynarodowego Roku Młodzieży «Abyście umieli zdać sprawę z nadziei, która jest w was» (Rzym, 31 marca 1985)", w Młodzież nadzieja Kościoła. Orędzia na Światowe Dni Młodzieży, red. Ewa Dębnicka-Szmagier (Warszawa: Instytut Wydawniczy PAX, 2005), 18-9. 
Formacja stypendystów ma prowadzić również do tworzenia wspólnoty duchowych dzieci Jana Pawła II, jednej rodziny fundacyjnej, a przez to do odkrywania własnego miejsca we wspólnocie Kościoła oraz poczucia odpowiedzialności za budowanie w świecie cywilizacji miłości. Ważnym wymiarem jest również troska o rozwój społeczny, a przede wszystkim zaangażowanie w działalność charytatywną, która jest jednym z wymogów przyznawania stypendiów. Ponadto działalność Fundacji prowadzi do kształtowania u podopiecznych postawy patriotyzmu - poprzez poznawanie dziedzictwa narodowego, odwiedzanych miejsc mających ważne znaczenie historyczne, wychowywanie do miłości i przywiązania do Ojczyzny ${ }^{30}$.

W ciągu roku formacja stypendystów odbywa się w poszczególnych diecezjach, podczas organizowanych przez koordynatorów spotkań, rekolekcji, dni skupienia. Raz w roku młodzież gromadzi się na wakacyjnym obozie formacyjno-integracyjnym. Obecnie odbywają się trzy takie obozy. Jeden przeznaczony jest dla uczniów szkoły podstawowej i średniej, drugi dla maturzystów, a trzeci dla studentów, tworzących w niektórych miastach wspólnoty akademickie ${ }^{31}$.

\section{EFEKTY FORMACYJNE DZIAŁALNOŚCI FUNDACJI}

Stypendyści - poprzez swoje postawy, zaangażowanie, świadectwo wiary, wcielanie w życie i rozkrzewianie papieskiego nauczania - postrzegani są jako „żywy pomnik" Jana Pawła II. Są to osoby zaangażowane w działalność parafii, szkoły, różnych instytucji społecznych i charytatywnych. Aktywnie włączają się w przygotowanie i przeprowadzenie corocznych obchodów Dnia Papieskiego.

$Z$ biegiem lat wielu z nich stawało się absolwentami Fundacji. Niektórzy pozostawali w stałym kontakcie z organizacją, służąc swoją pomocą i zaangażowaniem. W tym gronie zrodziła się inicjatywa mająca na względzie $\mathrm{z}$ jednej strony podtrzymywanie nawiązanych przyjaźni, dalszą wzajemną integrację, z drugiej z kolei pielęgnowanie pamięci o osobie i nauczaniu Jana Pawła II. Szybko przystąpiono do wcielania w życie danego projektu i w maju 2012 roku, na mocy decyzji Sądu Rejonowego dla miasta stołecznego Warszawy, „Stowarzyszenie Absolwentów Dzieło” zostało wpisane do Rejestru Stowarzyszeń ${ }^{32}$.

\footnotetext{
${ }^{30}$ Por. Paulina SkóRnickA, ,Formacja chrześcijańska młodzieży podczas obozów wakacyjnych Fundacji «Dzieło Nowego Tysiąclecia»”, w Edukacja religijna wobec przemian kulturowych, red. Paweł Mąkosa (Lublin: Wydawnictwo KUL, 2019), 220-1.

${ }^{31}$ Por. KowalczyK, Geneza i rozwój Fundacji, 242-3.

${ }^{32}$ Por. Fundacja „Dzielo Nowego Tysiąclecia”, Raport 2016, 13.
} 
Członkowie Stowarzyszenia podjęli szeroką działalność na rzecz rodziny, ukazując jej ogromne znaczenie - zarówno w wymiarze indywidualnym, jak i społecznym. W kluczu prorodzinnych poczynań zorganizowali dwie konferencje naukowe. Pierwsza z nich, pod hasłem: „Rodzina się liczy!”, odbyła się na Uniwersytecie Warszawskim 16 maja 2013 roku. W czasie konferencji został poruszony temat społeczno-gospodarczej wartości rodziny. Zaprezentowano wyniki projektu badawczego podjętego przez grupę stypendystów studiujących na kierunkach humanistyczno-społecznych. Badania miały zasięg ogólnopolski i dotyczyły oczekiwań i postaw młodych ludzi w kwestii założenia rodziny i wychowania potomstwa. Ich celem było poszerzenie wiedzy i poszukiwanie przyczyn niedecydowania się polskich rodzin na większą liczbę dzieci. Oprócz członków Stowarzyszenia, wśród prelegentów znaleźli się specjaliści zajmujący się tematyką rodzinną. Kontynuacją i niejako pogłębieniem postulatów sympozjalnych stała się publikacja Niezrealizowany potencjał dzietności polskich rodzin, będąca raportem z przeprowadzonego projektu badawczego. Drugą konferencją, zorganizowaną w tym samym kluczu przez „Stowarzyszenie Absolwentów Dzieło", było - odbywające się dwa lata później - sympozjum naukowe na Uniwersytecie Kardynała Stefana Wyszyńskiego w Warszawie, pod hasłem: „Rodzina się liczy. Wizerunek rodziny prezentowany w mediach”33.

Istotną inicjatywą członków „Stowarzyszenia Absolwentów Dzieło” jest stworzenie i prowadzenie punktu przedszkolnego „Lolek”. Został on założony we wrześniu 2015 roku, w warszawskiej dzielnicy Mokotów. Początkowo przedszkole mogło przyjąć pięcioro dzieci, będących w wieku od 3 do 5 lat. Obecnie w „Lolku” jest miejsce dla cztery razy większej grupy, w przedziale wiekowym od 3 do 6 lat. Placówka stanowi przestrzeń propagowania i wdrażania w codzienne życie, już od najmłodszych lat, nauczania Papieża Polaka oraz pielęgnowania wartości prorodzinnych i patriotycznych. Już sama nazwa punktu przedszkolnego odsyła do osoby Jana Pawła II. W dzieciństwie mama Karola Wojtyły zwracała się do niego zdrobniale - „Lolek”. Działalność przedszkolna realizuje autorski program „Wzrastamy z Lolkiem” ${ }^{34}$. Kadra pedagogiczna, którą tworzą absolwenci Fundacji, troszczy się przede wszystkim o wychowanie dzieci według chrześcijańskich wartości i słów Jana Pawła II, które wypowiedział w siedzibie UNESCO:

w wychowaniu chodzi właśnie o to, aby człowiek stawał się coraz bardziej człowiekiem - o to, aby bardziej był, a nie tylko miał - aby więc poprzez wszystko, co ma, co posiada, umiał bardziej i pełniej być człowiekiem - to znaczy, aby również umiał bardziej być, nie tylko z drugim, ale także dla drugich ${ }^{35}$.

\footnotetext{
${ }^{33}$ Por. Fundacja „Dzielo Nowego Tysiąclecia”, Raport 2000-2015, 40-1.

${ }^{34}$ Por. „Punkt przedszkolny «Lolek»”, http://przedszkolelolek.p1/ [dostęp: 02.02.2020].

${ }^{35}$ JAN PAwel II, „Przemówienie do mieszkańców Tondo, dzielnicy slumsów (Manila, 18 lutego 1981)", w Dzieła zebrane, red. Paweł Ptasznik i in., t. 13, (Kraków: Wyd. M, 2009), 154.
} 
Stypendyści, w duchu wdzięczności za otrzymaną pomoc, są również zaangażowani w działalność misyjną. Siedmioro stypendystów i jedna osoba spoza podopiecznych Fundacji nawiązali współpracę z ojcami ze Zgromadzenia Misjonarzy Matki Bożej Pocieszenia i w ten sposób w 2016 roku uformowała się grupa „Dzieło na misji”. Podstawą jej działalności jest przede wszystkim animacja misyjna prowadzona w Polsce - poprzez spotkania w szkołach, parafiach czy wspólnotach, mająca na celu rozbudzanie ducha misyjnego. Oprócz szerokiej działalności w kraju wolontariusze odbywają wyjazdy misyjne. Ich głównym założeniem jest pomoc osobom, które ze względu na panującą biedę, niesprawiedliwość społeczną mają utrudniony dostęp do opieki medycznej, a także szkolnictwa. Ponadto są okazją do prowadzenia działalności ewangelizacyjnej. Do tej pory miały miejsce trzy wyjazdy misyjne. Pierwszy z nich odbył się w 2017 roku do Etiopii, kolejny, rok później, do Argentyny i trzeci, w 2019 roku, do Mongolii. Wolontariusze misyjni pragną dzielić się swoją wiarą, otrzymanymi od Boga talentami z innymi, jednocześnie odpowiadając na potrzeby społeczności lokalnych ${ }^{36}$.

Fundacja „Dzieło Nowego Tysiąclecia”, powołana w 2000 roku jako odpowiedź Kościoła na aktualne potrzeby społeczne, gospodarcze i edukacyjne, pomogła wielu młodym osobom, chcącym się kształcić i rozwijać swoje talenty. Niniejszy artykuł jest próbą przedstawienia konkretnego przykładu wychowawczej i charytatywnej posługi Kościoła, stanowiącej odpowiedź na wyzwania czasów współczesnych. W pierwszej kolejności do takich wyzwań należy zaliczyć dynamicznie dokonujące się przemiany kulturowe, obejmujące wszystkie płaszczyzny ludzkiego życia. W takiej perspektywie konieczna jest działalność wychowawcza, której celem jest integralny rozwój osoby ludzkiej. Stanowi ona jedno z założeń Fundacji, która jest także instytucją charytatywną. U podłoża tej działalności leży trudna sytuacja ekonomiczna, uniemożliwiająca wielu młodym, utalentowanym ludziom odpowiednią edukację i lepszy start w przyszłość. Po przeanalizowaniu tych uwarunkowań, mających wpływ na powstanie i rozwój Fundacji, przedstawiono działania podejmowane przez jej absolwentów. Dziś wielu z nich daje świadectwo wiary i społecznego zaangażowania jako wyraz wdzięczności za otrzymane wsparcie materialne i duchowe oraz owoc troski Kościoła o młode pokolenie.

\footnotetext{
${ }^{36}$ Por. „Fundacja «Dzieło na misji»”, http://www.dzielonamisji.pl/o-nas/wizja-i-misja/ [dostęp: 06.02.2020].
} 


\section{BIBLIOGRAFIA}

Bielawny, Krzysztof. „Sytuacja społeczno-polityczna w Polsce na przełomie tysiąclecia jako kontekst powstania Fundacji «Dzieło Nowego Tysiąclecia»”. Ateneum Kapłańskie 173, z. 2 (2019): 214-27.

DzIEwIECKI, Marek. „Wychowanie nastolatków a stawianie wymagan”. Zeszyty Formacji Katechetów 18, nr 3 (2018): 5-17.

„Fundacja «Dzieło na misji»”. http://www.dzielonamisji.pl/o-nas/wizja-i-misja/. Dostęp 06.02.2020.

FundaCJA „DZiElo Nowego TysiąCLECIA”. „Informacja o pracach Fundacji «Dzieło Nowego Tysiąclecia» w okresie kadencji Zarządu 2000-2004”. Archiwum Fundacji „Dzieło Nowego Tysiaclecia”, teczka 1. Sprawozdania: 1-9.

Fundacja „Dzielo Nowego Tysiąclecia”. Raport 2000-2015, red. Dariusz Kowalczyk i in. Warszawa, 2016.

Fundacja „DzieŁo Nowego Tysiąclecia”. Raport 2016, red. Anna Bonk i in., Warszawa, 2017.

FundaCJa „DZielo Nowego Tysiąclecia”. Raport 2017, red. Paweł Żulewski i in., Warszawa, 2018.

JAN Pawel II. Adhortacja apostolska „Ecclesia in America”. Meksyk, 1999.

JAN PAweŁ II. „Homilia podczas Mszy świętej dla młodzieży «Podstawowy problem ludzkiego życia» (Lizbona, 14 maja 1982)". W Podręcznik pokolenia JP2. Ojcowskie słowo do młodych świata, Polski i Lednicy, red. Hanna Koźmińska, 74-81. Poznań: Wyd. Duszpasterstwo Akademickie Dominikanów, 2008.

JAN Pawel II, „Homilia w czasie Mszy św. (Ełk, 8 czerwca 1999)”. W Jan Pawet II. Pielgrzymki do Ojczyzny. Przemówienia. Homilie, 1058-64. Kraków: Wyd. Znak, 2005.

JAN PAwę II. „Homilia w czasie Mszy św. odprawianej na Placu Zwycięstwa (Warszawa, 2 czerwca 1979)". W Dzieła zebrane, red. Paweł Ptasznik i in., t. 9, 30-3, Kraków: Wyd. M, 2008.

JAN PAWEE II. „List apostolski do młodych całego świata z okazji Międzynarodowego Roku Młodzieży «Abyście umieli zdać sprawę z nadziei, która jest w was» (Rzym, 31 marca 1985). W Młodzież nadzieją Kościoła. Orędzia na Światowe Dni Młodzieży, red. Ewa Dębnicka-Szmagier, 5-53. Warszawa: Instytut Wydawniczy PAX, 2005.

JAN PAWEe II. „Pastores dabo vobis”. Posynodalna adhortacja apostolska o formacji kapłanów we wspótczesnym świecie. Rzym, 1992.

Jan Pawel II. Przekroczyć próg nadziei. Jan Pawel II odpowiada na pytania Vittoria Messoriego, Lublin: RW KUL, 1994.

JAN PAWEe II. „Przemówienie do mieszkańców Tondo, dzielnicy slumsów (Manila, 18 lutego 1981)”. W Dzieła zebrane, red. Paweł Ptasznik i in., t. 13, 153-156, Kraków: Wyd. M, 2009.

JAN PaweŁ II. „Słowo z okna Pałacu Arcybiskupiego (Kraków, 21 czerwca 1983)”. W Podręcznik pokolenia JP2. Ojcowskie słowo do młodych świata, Polski i Lednicy, red. Hanna Koźmińska, 753-754. Poznań: Wyd. Duszpasterstwo Akademickie Dominikanów, 2008.

JAN PAWEŁ II. „Spotkanie z młodzieżą «Chrystus jest odpowiedzią na wasze pytania» (Caracas, 28 stycznia 1985)". W Podręcznik pokolenia JP2. Ojcowskie słowo do młodych świata, Polski i Lednicy, red. Hanna Koźmińska, 164-9. Poznań: Wyd. Duszpasterstwo Akademickie Dominikanów, 2008.

JAN PAwEe II. „Spotkanie z młodzieżą Szwajcarii romańskiej «Macie dać Kościołowi nową młodość» (Fryburg, 13 czerwca 1984)". W Podręcznik pokolenia JP2. Ojcowskie słowo do młodych świata, Polski i Lednicy, red. Hanna Koźmińska, 137-41. Poznań: Wyd. Duszpasterstwo Akademickie Dominikanów, 2008.

Kongregacja DS. Kleru. Directorium catechisticum generale. Ogólna instrukcja katechetyczna. Rzym, 1971.

KosteCKI, Janusz. Problemy równowagi rynkowej w polityce społeczno-gospodarczej. Warszawa: Wyd. WAP, 1988. 
KowalczyK, Dariusz. „Geneza i rozwój Fundacji Konferencji Episkopatu Polski «Dzieło Nowego Tysiąclecia»”. Ateneum Kaptańskie 173, z. 2 (2019): 228-46.

KRóLCZYK, Małgorzata. „Autorytet moralny - wyzwanie dla wychowawców współczesnej młodzieży”. Studia Leopoliensia 12(2019): 111-27.

Majewski, Mieczysław. Aktualne wyzwania katechetyczne. Kraków: Wyd. Poligrafia Salezjańska, 1997.

MąKosa, Paweł. „Znaki czasu dla katechezy w Polsce”. Verbum Vitae 35, nr 35 (2019): 459-76.

MieLNICKI, Krzysztof. „Rekrutacja i formacja stypendystów Fundacji «Dzieło Nowego Tysiąclecia» w diecezji drohiczyńskiej z pastoralnej perspektywy koordynatora”. Ateneum Kapłańskie 173, z. 2 (2019), 334-51.

Nycz, Kazimierz. „Szanowni państwo!”. W Raport 2000-2015, red. Dariusz Kowalczyk i in., 3. Warszawa, 2016.

Nycz, Kazimierz. „Wspólnie budujemy «żywy pomnik» Jana Pawła II”. W Raport 2000-2010, red. Marek Ziółkowski i in., 3. Katowice, 2011.

OLCZYK, Arkadiusz. „Horyzonty wychowania moralnego w nauczaniu Karola Wojtyły - Jana Pawła II”. W Wychowanie w refleksji Karola Wojtyty - Jana Pawła II. Wybrane aspekty, red. Mariusz Sztaba i Anna Różyło, 97-116. Lublin: Wyd. KUL, 2015.

PAlYGA, Jan. „Na drodze wiary i niewiary”. Communio 8, nr 3 (1988): 3-24.

Patlewicz, Radosław. Historia polityczna Polski: nowe spojrzenie, t. 2. Częstochowa: Wyd. 3DOM, 2018.

Pawee VI. Evangelii nuntiandi. Posynodalna adhortacja apostolska o ewangelizacji w świecie wspótczesnym. Rzym, 1975.

„Punkt przedszkolny «Lolek»”. http://przedszkolelolek.pl/ [dostęp: 02.02.2020].

SKóRNICKA, Paulina. „Formacja chrześcijańska młodzieży podczas obozów wakacyjnych Fundacji «Dzieło Nowego Tysiąclecia»". W Edukacja religijna wobec przemian kulturowych, red. Paweł Mąkosa, 211-25. Lublin: Wyd. KUL, 2019.

„Statut Fundacji «Dzieło Nowego Tysiąclecia»”. Częstochowa, 1999.

\section{FUNDACJA „DZIEŁO NOWEGO TYSIĄCLECIA” \\ JAKO ODPOWIEDŹ NA WYZWANIA WOBEC WYCHOWAWCZEJ I CHARYTATYWNEJ POSŁUGI KOŚCIOŁA}

\section{Streszczenie}

Sobór Watykański II zwrócił uwagę na zadania świeckich w Kościele i świecie. Efektem postanowień soborowych stało się dowartościowanie laikatu, a zwłaszcza ludzi młodych. Pod koniec XX wieku Kościół dostrzegł potrzebę objęcia duszpasterską działalnością formacyjną młodego pokolenia, które odpowiednio ukształtowane, przyczyni się do przekształcania struktur społecznych pod budowę cywilizacji miłości. Podjętą w tym czasie inicjatywą było powołanie przez Konferencję Episkopatu Polski Fundacji „Dzieło Nowego Tysiąclecia”. Jednym z celów organizacji jest niesienie pomocy materialnej uzdolnionej młodzieży z niezamożnych rodzin, zamieszkującej tereny wiejskie oraz odznaczającej się wysokim osiągnięciami w nauce. Program stypendialny, oprócz wsparcia finansowego, jest nastawiony także na formację chrześcijańską stypendystów w duchu nauczania Jana Pawła II. Podopieczni Fundacji, wdzięczni za otrzymaną pomoc, podejmują różne działania, stanowiące z jednej strony owoc formacji, a z drugiej potwierdzające przekonanie, że są ,żywym pomnikiem” Jana Pawła II, ponieważ żyją na co dzień wartościami, które głosił Ojciec Święty, i przekazują światu jego nauczanie.

Słowa kluczowe: młodzież; Fundacja „Dzieło Nowego Tysiąclecia”; program stypendialny; chrześcijańska formacja; Jan Paweł II. 